\title{
İslam Davetinin Mekke Döneminde Hz. Peygamber'in (s) Liderlik Stratejileri
}

\section{The Prophet Mohammad's (pbuh) Leading Strategies in the Mecca Period of the Islamic Invitation}

\author{
Dr. Öğr. Üyesi Eyüp KURT
}

\begin{abstract}
$\ddot{\mathbf{O} z}$
Yüce Allah tarafından gönderilen Allah Resûlü, (s) Mekke'de tebliğ görevini yerine getirirken lider oligarşisiyle uğraşmak zorunda kalmıştır. Hz. Peygamber'in (s) şirkin yerine tevhîdi ikâme etmeye dayalı çağrısı üzerine Mekke müşrikleri, kurulu düzenlerinin bozulacağı endişesiyle tedirgin olmuşlardır. Bundan dolayı Dârunnedve riyâsetindeki örgütlü yapıyı organize ederek İslam davetine karşı ayetlerde "mekr" olarak ifadesini bulan tuzaklar kurmuşlardır. Buna karşı Allah Resûlü (s) onların tuzaklarını boşa çıkarmak için vahyin rehberliğinde bir dizi strateji tatbik etmiştir. Bunları; Hâşimîlerle ilgili Olanlar, Hâşimîler Dışındaki Kureyş Liderlerle ilgili Olanlar ve Kureyş’i Çevre Kabileler Üzerinden Kazanma Amacına Yönelik Olanlar şeklinde üç başlık altında ortaya koymaya çalıştık. Allah Resûlü'nün (s) tebliğ sürecinde izlediği stratejilerin neler olduğu ve nasıl tatbik edildiği hususu, bu görevi devam ettirmeyi şiar edinen müslümanların bilmesi gerektiği gibi bu konuyla ilgilenen herkes için de önem arz etmektedir. Arap kabile yapısında liderlerin/şeyhlerin belirleyici oluşu, İslam'ın tebliği sürecinde Mekke'de engelleyici, Medine'de ön açıcı bir fonksiyon icra etmiştir. Ancak bu çalışmada her iki dönemi birlikte ele alma yerine, bir makale boyutunu aşacağı düşüncesiyle sadece Mekke süreci üzerinde durulmuştur. Çalışmada konuyla ilgili kaynakların aktardığı rivayetler analiz edilerek bahsi geçen stratejiler belirlenmeye çalışılmıştır. Sahâbe-i Kirâm da İslam davetiyle ilgili gereken mücadeleyi yapmaktan geri kalmamıştır. Ancak Kur'an-1 Kerim İslam’ın tebliğ faaliyetini daha çok Hz. Peygamber (s) üzerinden anlattığ 1 için makalede de aynı yöntem takip edilmiştir.
\end{abstract}

Anahtar Kelimeler: Siyer, Mekke dönemi, Hz. peygamber, kabile, Mekke müşrikleri

Makale Türü: Araştırma

\begin{abstract}
The Prophet, sent by the Almighty, had to deal with the leader oligarchy while fulfilling his duty in Mecca. The Prophet's call to substitute unity instead of partner, the Meccan polytheists were worried that their order would be disrupted. Therefore, they set traps against the invitation of Islam. Thereupon, the Prophet applied a series of strategies under the guidance of revelation in order to void their traps. The issue of what the strategies followed by the Prophet in the process of inviting and how they were implemented is important for everyone who is interested in this issue, as Muslims who take this duty should know. The determination of leaders / sheikhs in the Arab tribal structure has performed a preventive function in Mecca and a pioneering function in Medina during the process of conveying Islam. However, in this study, instead of discussing both periods together, we focused only on the Mecca process with the idea that it would exceed the dimension of an article. In our study, the mentioned strategies were tried to be determined by analyzing the narratives conveyed by the relevant sources. Companions did not fail to struggle with the invitation to Islam. However, we tried to follow the same method in our study because the Quran describes the teaching activity of Islam mostly through the Prophet.
\end{abstract}

Keywords: Prophetic biography, Mecca period, prophet Mohammad, tribe, Mecca polytheists

\footnotetext{
${ }^{1}$ Afyon Kocatepe Üniversitesi, İslami İlimler Fakültesi, ekurt@aku.edu.tr.

Atıf için (to cite): Kurt, E. (2021). İslam davetinin Mekke döneminde Hz. Peygamber'in (s) liderlik stratejileri. Afyon Kocatepe Üniversitesi Sosyal Bilimler Dergisi, 23(2), 546-562.
} 
Paper Type: Research

\section{Giriş}

Yüce Allah tarafindan "tüm insanlığa"2 "âlemlere rahmet olarak gönderilen"3 Allah Resûlü (s), Mekke'de tebliğ görevini yerine getirirken lider oligarşisiyle uğraşmak zorunda kalmıştır. Onlar Hz. Peygamber'in (s) şirk düzenlerini bozacağı endişesiyle çok tedirgin olmuşlardır. Bundan dolayı İslam davetine karşı çok sayıda tuzak kurmuşlardır. Buna karşı Allah Resûlü (s) onların tuzaklarını boşa çıkarmak için vahyin rehberliğinde bir dizi strateji tatbik etmiştir. Özellikle Siyer alanında telif edilmiş eserlerde Hz. Peygamber'in mücadelesi uzun uzun anlatılmıştır. Biz araştırmamızda bahsi geçen mücadeleyi yeniden anlatacak değiliz. Hz. Peygamber'in (s) yaklaşık 13 senelik Mekke sürecinde müşriklerin tuzaklarına karşı nasıl stratejiler izleyerek hedefe ulaşmaya çalıştığını ortaya koymaya çalışacağız. Allah Resûlü’nün (s) tebliğ sürecinde izlediği stratejilerin neler olduğu ve nasıl tatbik edildiği hususu, bu görevi devam ettirmeyi şiar edinen müslümanların bilmesi gerektiği gibi bu konuyla ilgilenen herkes için de önem arz etmektedir. Çünkü Hz. Peygamber (s) diğer hususlarda olduğu gibi bu konuda da Yüce Allah tarafindan müslümanlara "üsve-i hasene/en güzel örnek"4 ve "âlemlere rahmet" olarak takdim edilmiş̧ir. Aynı zamanda bu hususun bilinmesi, yaşadığı dönemden itibaren üstlendiği misyon ile tarihin gidişatına damgasını vuran Hz. Peygamber'in (s) tanınmasına da katkı sağlayacaktır. Arap kabile yapısında liderlerin/şeyhlerin belirleyici oluşu, İslam'ın tebliği sürecinde Mekke'de engelleyici, Medine'de ön açıcı bir fonksiyon icra etmiştir. Ancak biz bu çalışmamızda her iki dönemi birlikte ele alma yerine, bir makale boyutunu aşacağı düşüncesiyle sadece Mekke süreci üzerinde durduk. Ancak yeri geldikçe Cahiliye dönemine veya İslam davetinin Medine dönemine hadiselerin sebeplerine veya sonuçlarına değinmek adına atıflar yapmak durumunda kaldık. Çalışmamız Allah Resûlü'nün (s) uygulamaya koyduğu stratejilerin belirlenmesi için, "Literatür-Kaynak" taramasına dayanan bir araştırmadır. Bunun için konuyla ilgili kaynakların aktardığı rivayetler analiz edilerek çıkarımlar yapılmaya çalışılmıştır. Aynı zamanda ilgili araştırmalardan da istifade edilmiştir. Çalışmamızda İslam davetini engellemeye yönelik müşrikler tarafından icra edilen çalışmalara Kur'an'ın tercihinden dolayı mekr/tuzak, ${ }^{6}$ Hz. Peygamber'in (s) müşriklerin engellemelerini ortadan kaldırmaya yönelik çalışmaları için hikmet/strateji kelimelerini kullanmayı tercih ettik. Aslında İslam davetinin yegâne kahramanı tek başına Hz. Peygamber değildir. Sahâbe-i Kiram da bu konuda gereken mücadeleyi yapmaktan geri kalmamışlardır. (Kurt, 2020, s. 142) Ancak Kur'an-1 Kerim İslam'ın tebliğ faaliyetini daha çok Hz. Peygamber üzerinden anlattığı için, çalışmamızda biz de aynı yöntemi izleyerek, özellikle gerekli olmadıkça sahabeleri söz konusu etmedik.

\section{Davet-Strateji İlişkisi}

Davet kelimesi terim olarak "İslam'a ve İslam esaslarının uygulanmasına çağrı" anlamına gelir. Tebliğ de "Elçilerin vahiy yoluyla aldıkları bilgiyi insanlara ulaştırması" demektir. (Çağrıc1, 1994, s. 9/16) Kur'an-1 Kerim'de peygamberlerin görevini ifade etmek üzere bunların dışında 'irşad, vaaz, nasihat, inzar, tebşir, emr-i bi'l-marûf, nehy-i ani'l-münker (Boynukalın, 2011, s. 40/218) gibi terimler de davet anlamında kullanılmıştır. Bunların anlamları yönünden aralarında nüanslar olmakla birlikte hepsinin ortak noktası elçilerin Allah'tan aldıkları vahiyleri insanlara ulaştırmalarıdır.

Çerçevesini belirlemeye çalıştı̆̆ımız "davet/çağrı” görevinin Hz. Peygamber tarafından nasıl yerine getirileceğine dair ilkeler de Yüce Allah tarafından ilgili ayetlerde ${ }^{7}$ ortaya

\footnotetext{
2 es-Sebe 34/28.

${ }^{3}$ el-Enbiyâ $21 / 107$

${ }^{4}$ el-Ahzâb 33/21.

5 el-Enbiyâ 21/107.

${ }^{6}$ el-Enfâl 8/30.

${ }^{7}$ en-Nahl 16/125.
} 
konulmuştur. $\mathrm{Bu}$ çerçevede "insanlar üzerinde bir zorba olunmaması", 8 "dinde zorlama yapılmaması", ${ }^{9}$ hikmet ve güzel öğüt ile davet edilmesi, en güzel şekilde mücadele edilmesi" ${ }^{10}$ gibi ilkeler belirlenmiştir.

Allah Resûlü'nün (s) 23 yıllık davet sürecine bakıldığında tebliğin dört aşamada gerçekleştirildiğini söylemek mümkündür. Bunlar; "hazırlık, kadro oluşturma, kitleleşme ve devletleşme" (Çağrıcı, 1994, s. 9/17-19) merhaleleridir. Hazırlık aşamasında, kendisinin bir insan olarak bu göreve her yönüyle hazırlanması söz konusu olmuştur. Bu süreç tamamlandıktan sonra artık diğer insanlara davete başladığını ve kendisine çekirdek bir kadro oluşturduğunu görüyoruz. Akabinde oluşan bu kadronun da desteğini alarak kitlelere açıldığını ve nihayet uygun bir mekân olan Medine şehrine hicret ederek devletleşme sürecinin başlatıldığ görülmektedir. İzlenen bu stratejinin, "Rabbinin yoluna hikmet ile davet et"11 emrinde yerini bulan hikmet kavramı kapsamında olduğu kanaatini taşıyoruz.

Strateji ise, "önceden belirlenen bir amaca ulaşmak için tutulan yol veya bir ulusun veya uluslar topluluğunun, barış ve savaşta benimsenen politikalara en fazla desteği vermek amaciyla politik, ekonomik, psikolojik ve askerî güçleri bir arada kullanma bilimi ve sanatı" olarak tanımlanmıştır. Aynı zamanda "Bir kişi veya işletmenin bir vizyona sahip olması ve buna ulaşmak için bütün kaynak ve enerjisini yoğunlaşmış bir irade ile harekete geçirmesidir. Bununla birlikte strateji, rekabetçi çevrede ortaya çıkan firsatlarla organizasyonun kaynaklarının eşleştirilmesini sağlayan rasyonel bir süreçtir. (Kahveci, 2008, s. 1)

Hz. Peygamber (s) açıtan tebliğe başladıktan sonra Hz. Ebû Bekir, Hz. Ömer, Hz. Hamza gibi toplumda bir şekilde ağırlığı olan kimselerin İslam'1 tercih ettikleri görülünce, müşrik liderleri Allah Resûlü (s) ile strateji tanımlarında sözü edildiği gibi, rekabet etmeye başlamışlardır. (İbn Hişâm, 1992, s.1/194); (İbn Sa'd, 1968, s.1/201) İşte bu süreçte karşılıklı olarak bir taktik savaşının ortaya çıktığını söyleyebiliriz. Bu noktada stratejilerin tatbik edilmesi tamamen gönüllülük esasına dayanan "inanma" eylemine halel getirmez mi diye bir soru akla gelebilir? Aslında tatbik edilen stratejilere, "Rabbinin yoluna hikmet ile davet et..." ayetinde ${ }^{12}$ ifadesini bulan usûl olarak bakılabilir. Ya da inanmak isteyenlere İslam nimetinin ulaştırılmasının önündeki engellerin kaldırılması faaliyeti olarak değerlendirilebilir. Tıpkı İslam fetihlerinin, inanma özgürlügünün önündeki engellerin kaldırılarak İslam ile ona inanmak isteyenlerin buluşturulması hadisesinde (Fayda, 1995, s.12/467-470) olduğu gibi. Zaten tebliğ için kıtal yapılmasının meşrû görülmesi başka bir şekilde izah edilemez. Çünkü İslam'a göre bir kişiyi haksız yere öldürmek bütün insanları öldürmek kadar günah ve bir kimsenin yaşamasına vesile olmak da bütün insanlığı yaşatmak kadar büyük sevaptır. ${ }^{13}$

Allah Resûlü'nün (s) Medine'ye hicreti hususunda müşrik liderlerin Dârunnedve'deki müzakerelerini ayrıntılı olarak dile getiren Enfâl suresinin 30. ayetinde bu durum mekr/tuzak kelimesiyle ifade edilmiştir. Strateji kavramındaki müspet anlamdan yola çıkarak ilgili ayetlerde $^{14}$ kullanıldığı üzere, Hz. Peygamber'in (s) uygulamaya koyduğu yöntemler için de hikmet, müşriklerin her türlü engelleme faaliyetleri için de mekr/tuzak kelimesini kullanmanın, mefhumu ifade için daha uygun olacağı kanaatindeyiz.

\section{Mekke Toplumunun Sosyal Yapısı}

İslam öncesi Arap toplumu, yaşadıkları çevrenin gerektirdiği sosyal bir model olan kabile sistemine göre hayatını idame ettirmiştir. Kabile mensupları genellikle aynı atadan gelen insan topluluklarından müteşekkildi. Çevre şartları çekirdek aile biçimindeki bir yapılanmaya imkân vermediği için çok sayıda ailenin bir araya gelmesiyle kabileyi oluşturmuşlardı. Kabileyi

\footnotetext{
8 el-Gâşiye $88 / 22$.

9 el-Bakara $2 / 256$.

10 en-Nahl 16/125

11 en-Nahl 16/125.

12 en-Nahl 16/125

13 el-Mâide 5/32)

14 en-Nahl 16/125.
} 
oluşturan aile birliklerinin oluşturduğu alt basamakların (fâsıle, ammâre, fahz, batın) liderlerinin bir araya gelmesiyle oluşan oligarşik yapı, kabilenin yönetim kademesini oluşturmuştur. (Cevad Ali, 1993, s. 4/316-319) Bu yapı, kabileyi değişik mahfillerde temsil etmesi gibi sebeplerle, içlerinden yaşça daha ileri, daha zengin ve daha çok temayüz eden biri reis olarak seçilirdi. Adına şeyh/reis/seyyid denilen ve eşitler arasında birinci durumda olan kabile liderinin gerek kabile mensupları ve gerekse diğer reislere karşı mutlak otoritesi söz konusu değildi. Kabileyi ilgilendiren konularda oligarşik yapı, aralarında yaptıkları istişare neticesinde kararlar alırlardı. ( Hitti, 1989, s. 1/52; Cevad Ali, 1993, s. 4/316; Kurt, 2000, s. 25; Çelikkol, 2003, s. 222; Avc1, 2010, s. 39/49; Demircan, 2018, s. 1/120;)

Kabilede alınan karar herkesi bağlayıcı nitelikte olup aykırı hareket edenler çöl güvenlik sistemi olarak adlandırılabilecek "himâye"den yoksun bırakılmaktaydı. Hiç bir güvenlik sisteminin olmadığı çöl şartlarında "hal' edilmek" (Bozkurt, 1998, s. 18/56) tamamen korumasız kalmak demekti. Bu yüzden kabile mensupları genellikle alınan kararlara sadık kalırlardı. Bir örnek olması kabilinden Hz. Peygamber'in (s) sürdürdüğü İslam davetine karş1 kendi kabilesinde bir kabile kararı alınmış değildir, Ebû Tâlib'in kabile şeyhi karizmasını kullanarak Hz. Peygamber'e (s) destek çıkması (İbn Hişâm, 1992, s. 1/121; İbn Sa'd, 1968, s. 1/201) da, bu süreçte Ebû Leheb'in düşmanlık etmesi (İbn Hişâm, 1992, s. 1/237) de kişisel inisiyatif olarak değerlendirilmelidir.

Kabileyi oluşturan bireyler rastgele bir araya gelmiş kalabalıklar değildi. Onlar, "haklı da olsa haksız da olsa kabiledaşına arka çık" şeklinde sloganize edilebilecek asabiyet duygusuyla birbirleriyle kenetlenmişlerdi. Bu manevi duygu, acımasız çöl şartlarında kabilenin tüm fertlerini birbirine kenetleyerek adeta yekvücut hale getirmişti. (Apak, 2004, s. 20; Koçyiğit, 2015, s. 10-11) Ebû Tâlib'in müslüman olmamasına rağmen Hz. Peygamber'i (s) sonuna kadar desteklemesi, asabiyet anlayışının gereğiydi.

Ayrıca kabile birlikleri veya ortaklıkları diye tanımlanabilecek hilfler yapılmıştı. Buna göre bir kabile, düşmanlarına karşı daha güçlü hale gelmek için kendisine denk gördüğü birçok kabileyle ittifaklar kurmuştu. Hz. Peygamber'in (s) de destekçilerinden olduğu daha çok Mekke şehrindeki mağdurların hakkını savunmak üzere oluşturulan "Hilfu'l-fudûl" bunlardandır. (Hamidullah, 1998, s.18/32-33; Apak, 2001, s. 191) Ayrıca Kureyşlilerin alt kollarının birbirlerine karşı güç birliği yapmak için oluşturduğu "mutayyebûn" ve "ahlâf" (Algül, 1998, s. 18/32-33) da sözünü ettiğimiz hilflerdendir.

Risâlet öncesi dönemde adeta bir "panteon" haline getirilen Kâbe, Adnânî Arapları'nın atası Hz. İbrahim ve oğlu Hz. İsmail tarafindan daha önce var olan temelleri üzerine inşa edilmiştir. ${ }^{15}$ Beytullah olarak da adlandırılan ve yeryüzünde tevhid inancının sembolü olarak kabul edilen Kâbe, özellikle Adnânî Arapları tarafindan kutsal olarak kabul edilirdi. Merkezinde Kâbe'nin yer aldığı hac ibadeti ve hemen yanı başında ortaya çıkan Zemzem suyu bu ma'bed'in ve Mekke şehrinin önemini bir kat daha artırmıştır. Hem sözü edilen Arap topluluklarının hac ibadeti için buraya gelmeleri, hem de muhtelif sebeplerle bölgeden intikal etmekte olan yolcuların uğramaları, süreç içinde şehrin önemli bir merkez haline gelmesini sağlamıştır. (Bozkurt-Küçükaşc1, 2003, s. 28/555-563)

$\mathrm{Bu}$ durum, zaman içinde şehirde hem yerel hem de uluslararası nitelikte panayırların kurulmasına sebep olmuştur. Böylece Mekke şehri hem dini hem de ticari bir nitelik kazanmıştır. Daha sonraki süreçlerde belki şehri daha önemli hale getirmek veya nispeten azalan itibarını artırmak amacıyla Suriye'den bir put getirilerek Kabe'ye yerleştirilmiştir. (İbnü'lKelbî, 1969, s. 26;İbn Hişâm, 1992, s. 1/56) Giderek sayıları artan putların, sadece bu ma'bette bulunmasıyla yetinilmeyip konutlarda put köşesi oluşturulmuş hatta yolculuklarda minyatür put bulundurulmuştur. Putların bu derece yaygınlaşmasını sağlayan ana etken hiç kuşkusuz onlara yüklenen anlam olmalıdır. Kutsal kitabımızdan öğrendiğimize göre putlar, insan ile Allah

15 el-Bakara 2/125. 
arasında aracılık yapan ${ }^{16}$ nesneler olup aynı zamanda onlara tapan insanlar için Allah katında şefaatçilerdir. ${ }^{17}$ Böylece putlar sayesinde mabetleriyle ve çeşitli ibadet şekilleriyle adına putperestlik denilen yeni bir din oluşturulmuştur. (Güç, 2007, s. 34/365-368)

\section{Hz. Peygamber'in (s) İslam'ı Tebliğinde Kabile Reisleri/Liderler}

\subsection{Hz. Peygamber’in (s) Hâşimî Liderlerle İlgili Stratejileri}

Allah Resûlü, (s) Kureyş boyunun Benû Hâşim koluna mensuptur. Aşireti oluşturan bireylerin ancak kabile kimlikleriyle bir anlam ifade ettiği kendi toplumunda, Hz. Peygamber'in (s) öncelikle aşiretinin desteğini alma mecburiyeti vardı. Diğer bir ifadeyle, kendisinin peygamber olduğunu kanıtlayan bir vesikanın olamayacağı bir durumda, muhataplarına karşı inandırıcılık sağlayabilmesi öncelikle kabilesinin kendisine inanmış ve destek veriyor olmasını zaruri kılıyordu. Kişinin ait olduğu kabileyle ilgili bahsi geçen özel durumlardan dolay1, öncelikle Hz. Peygamber'in (s) kendi kabilesi ile ilgili nasıl stratejiler uygulamaya koyduğunu irdelememiz gerekmektedir.

Kabilelerin özelliklerinden biri de oligarşik bir yönetim sistemine sahip olmalarıdır. $\mathrm{Bu}$ durum, yönetimle ilgili bir kararın alınmasında birden çok kimsenin etkisini lüzumlu hale getirdiğinden, Allah Resûlü'nün (s) sadece kabile reisi ile ilgili tatbik ettiği stratejinin ortaya konulması konumuzun aydınlatılması açısından yeterli olmayacaktır. Bunun yerine kabilenin yönetimi noktasında etkili olan diğer zevata karşı nasıl tavır izlendiği konusu da önem kazandığından, onlarla ilgili stratejiler de tahlil edilmeye çalışılacaktır. Bu çerçevede önce kabile reisi Ebû Tâlib, ardından Ebû Leheb ve sonra da Hz. Abbas ile ilgili stratejileri üzerinde durulacaktır.

\subsubsection{Ebû Tâlib ile İlgili Olanlar}

Hz. Muhammed (s) Allah tarafından peygamber olarak görevlendirildiğinde, (m.610) bizzat kendisinin de mensup olduğu kabile olan Benû Hâşim'in riyâsetini büyük amcası Ebû Tâlib deruhte ediyordu. Ebû Tâlib, Allah Resûlü'nün (s) o dönemde hayatta olan amcalarından Ebû Leheb ile birlikte İslam'1 hiç bir zaman benimsemeyen iki amcadan biridir. Hz. Peygamber onun müslüman olmasını sağlamak için o derece gayret sarf etmiştir ki, bu konuda ilahi ikazlara maruz kalmıştır, ${ }^{18}$ denilebilir.

Ebû Tâlib, daha gizli tebliğ döneminde oğlu Hz. Ali ile yeğeni Hz. Peygamber'in (s) birlikte namaz kıldıklarına şahit olmuştur. Ne yaptıklarını sorduğunda gerekli açıklamayı yapan Hz. Peygamber (s), kendisini de İslam'a davet etmiştir. Bu talebe olumsuz cevap veren amca, (İbn Hişâm, 1992, s. 1/167) belki de kardeşleri arasında İslam dini konusunda ilk haberdar olan kimsedir. Daha sonraki açiktan tebliğ sürecinde davete yine olumsuz cevap verecektir.

Açıktan davetin sürdüğ̈ süreçte, ilgili ayetlerin ${ }^{19}$ müşriklerin putlarını hedef almaya başladığı dönemlerden başlamak üzere, Mekke müşriklerinin elebaşları Hz. Peygamber'in (s) daveti konusunda kendisiyle defalarca görüşmüşlerdir. Ebû Tâlib bu görüşmelerin hiçbirinde, ne pahasına olursa olsun, onların taleplerine olumlu cevap vermemiştir. (İbn Hişâm, 1992, s. 1/167) Bu görüşmelerden bir kısmı var ki, hem tebliğin seyriyle ilgili önemli bir dönüm noktası olmuş, hem de Allah Resûlü'nün (s) liderlerle ilgili stratejisini anlamamıza katkı sağlayacak nitelikte olduğundan, örnekler üzerinden konuyu açmaya çalışalım.

Müşrik liderler önce Ebû Tâlib'in, yeğeniyle görüşerek sorunu çözmesini istemişlerdir. (İbn Hişâm, 1992, s. 1/175; İbn Sa'd, 1968, s. 1/201-203) Anlaşıldığı kadarıyla Ebû Tâlib, konuyla ilgili yeğeniyle görüşmemiştir bile. Yeğeninin davasından vazgeçmesi talebini, dozunu biraz artırarak talep etmeleri üzerine Ebû Tâlib yeğeniyle konuyu görüşmüştür. Kendisine

\footnotetext{
16 ez-Zümer 39/3.

17 Yûnus 10/18.

${ }^{18}$ el-Kasas 28/56; et-Tevbe 9/113.

19 el-Enbiyâ 21/98-100.
} 
yapılan baskılara dayanamayacağını ifade ederek yeğeninden davetinden vazgeçmesini isteyince Allah Resûlü, (s) belki de amcasının himâyesinden vazgeçeceğini düşünerek ona son derece etkili ve ne kadar kararlı olduğunu net bir şekilde ifade eden cevabını vermiştir: "Güneşi sağ elime, ayı da sol elime verseler, yine de davamdan vazgeçmem. Ya Allah bu dini üstün kılar, ya da ben bu uğurda ölürüm”. (İbn İshâk, 1978, s. 154; İbn Hişâm, 1992, s. 1/177; Belâzûrî, 1996, s. 1/230) Hz. Peygamber'in (s) amcasına verdiği oldukça kararlı cevap, onu fazlaca etkilemiş olmalı ki, bir veli ve kabilenin reisi olarak, bedeli ne olursa olsun kendisini himâye etmeye devam edeceğini ifade etmiştir. Bundan sonra Kureyş müşriklerinin bir adım daha atarak babası Abdülmuttalib'in kendisine emanet ettiği yeğenini, Mekke'nin gençlerinden Umâre b. Velid karşıllı̆ında kendilerine teslim etmesini talep etmişlerdir. Kureyş büyüklerinden olan Ebû Tâlib de mealen "ben bu talebinizi duymamış olayım" diyerek onlara son derece çirkin bir istekte bulunduklarını dile getirmiştir. (İbn Hişâm, 1992, s. 1/177; İbn Sa'd, 1968, s. 1/202)

Dârunnedve riyâsetindeki Mekke oligarşik yönetimi, bütün bu olup bitenlerden sonra Allah Resûlü'nün (s) davasından vazgeçirilmesinin Benû Hâşim'in reisi vasıtasıyla mümkün olamayacağını düşünerek topyekûn Allah Resûlü'nün kabilesini cezalandırma yöntemini tercih etmiş̧tir. Buna göre Hz. Peygamber'in (s) kabilesini ve onlara destek veren Muttaliboğullarını düşman ilan ederek onlara karşı sosyal ve ekonomik ambargo uygulayacaklardır. Yaklaşı üç yıl (616-19) devam ettiği bilinen bu cezalandırma sürecinde Ebû Tâlib, kendi adını taşıyan mahallede kabile mensuplarını bir araya getirerek hep birlikte hayata tutunmaya çalışmışlardır. Çok sıkıntılı günler yaşamış olsalar da tercih edilen bu cezalandırma, kabile mensuplarının birbirlerine daha da kenetlenmeleriyle sonuçlanacaktır. (Söylemez, 2006, s. 13) Ebû Leheb'in dışında başta reis Ebû Tâlib olmak üzere hiçbir kabile mensubu Hz. Peygamber'e (s) karşı dışlayıcı hatta soğuk bir tavır içinde olduğuna dair malumat sahibi değiliz. (İbn Hişâm, 1992, s. 1/250-255; İbn Sa'd, 1968, s. 1/208-210)

Bu hadiseden kısa bir süre sonra önce Ebû Tâlib arkasından da Hz. Hatice hayatını kaybetmiştir. ( İbn Hişâm, 1992, s. 1/280; Belâzûrî, 1996, s. 1/237) Hz. Peygamber'e (s) beşer düzleminde maddi ve manevi destek kaynağ 1 olan bu iki şahsın ahirete irtihal etmesi, Allah Resûlü'nü (s) o kadar çok üzmüştür (Savaş, 2017, s. 17) ki, onun hayatını kaleme alan siyer müellifleri bu seneyi "Hüzün Y1lı" (Belâzûrî, 1996, s. I/237) olarak adlandırmayı uygun görmüşlerdir. Bundan böyle kabile desteğini kaybeden Hz. Peygamber, daha çok kendisi ve arkadaşları için sığınak aramaya başlayacaktır.

Burada dikkat çeken önemli bir husus, amca Ebû Tâlib'in müslüman olmamasına rağmen Allah Resûlü'nü himâye etmesidir. Bunun sebebi olarak kaynaklarımız Ebû Tâlib'in yeğenine olan düşkünlüğünü, babasının emanet olarak bırakmasını ama bunlardan çok daha önemlisi kabile asabiyetini gösterirler. Bunun en önemli göstergesi, vefatından sonra riyasete getirilen Ebû Leheb'in de Hz. Peygamber'e (s) kabile şeyhi olarak destek vermesidir. (İbn Hişâm, 1992, s. 1/215;Apak, 2004, s. 33; Kurt, 2012, s. 298) Hâlbuki Ebû Leheb, rivayetlerin bize aktardığına göre İslam davasına ilk muhalefet edenlerdendir. Sadece kendi imkânlarıyla değil, Dârunnedve desteğini de arkasına alarak Allah Resûlü'ne karşı en önemli muhalefeti yapan Ebû Cehil bile isim verilerek ayetlerde yerden yere vurulmazken Ebû Leheb'in karısıyla birlikte lanetlenmesi ${ }^{20}$ belki de bu yüzdendir.

Ana hatlarını ortaya koymaya çalıştı̆̆ımız amca-yeğen ilişkilerinde Hz. Peygamber, (s) bahsi geçen desteği davasının yayılmasını sağlamak için faydalı bir şekilde değerlendirmiştir. Davetini reddetmesine rağmen amcasının desteğini değerlendirme stratejisi, Allah Resûlü'nün (s) yaklaşık 13 yıllık Mekke sürecindeki başarılarının beşer düzlemindeki temelini oluşturduğu söylenebilir. Sonuç olarak Hz. Peygamber, (s) doğup büyüdüğü toplumun cârî sosyal yapısından ve risalet öncesi elde etmiş olduğu olumlu imajına ilaveten uygulamaya koyduğu ustaca strateji sayesinde, davasının Kureyş nezdinde zemin bulmasını ve nispî düzeyde de olsa yayılmasını sağlamayı başarmıştır.

${ }^{20}$ Leheb 111/1-5. 


\subsubsection{Ebû Leheb ile İlgili Olanlar}

Mekke şehrinin önde gelenlerinden olan Ebû Leheb, Benû Hâşim içerisinde ikinci örneği olmayan bir kimse olmuştur. Geleneğe göre, ne pahasına olursa olsun, kabile mensuplarının birbirini desteklemesi asabiyet anlayışı gereğince vazgeçilmez bir değer (Azimli, 2015, s. 57) olmasına rağmen Ebû Leheb, gerek Hâşimîlerin ş̧eyhi olmadan ve gerekse reisi olduktan sonra yeğeni Hz. Peygamber'e (s) destek olmamıştır. Bununla da kalmayarak risâletten önceki dönemde iki oğlunu evlendirdiği Hz. Peygamber'in (s) kızlarını oğullarına baskı yaparak onlardan ayrılmalarını sağlamıştır. (İbn Hişâm, 1992, s. 1/481) Dahası Hz. Peygamber'e (s) komşu da olan Ebû Leheb, bu mekânsal yakınlığı dahi muhtelif şekillerde Allah Resûlü'ne (s) kötülük yapmanın bir aracı olarak kullanmıştır. (İbn Sa'd, 1968, s. 1/ 201)

Hz. Peygamber'e (s) karşı sergilenen söz konusu kindar davranışlar genellikle Ebû Leheb'in karısının, Ebû Süfyan'ın kız kardeşi (İbn Hişâm, 1992, s. 1/237) olmasıyla veya Allah Resûlü'nün (s) babası Abdullah ile Ebû Leheb'in farklı anneden doğmuş olmalarıyla izah edilmeye çalışılmıştır. Geleneksel rivayetlerde yeri olmamakla birlikte konuyla ilgili araştırmalar yapan Uri Rubin bu durumu bir adım daha ileri götürerek Ebû Leheb'in Hz. Peygamber'in (s) öz amcası olmadığı iddiasıyla (Kapar, 1994, s. 10/178-179) izah etmeye çalışmıştır.

Her ne sebeple olursa olsun Allah Resûlü'ne (s) karşı son derece kindar bir tavır takınan Ebû Leheb, bizzat isim verilerek lanetlenen tek müşrik olarak ayetlerdeki yerini almıştır. En az kendisi kadar karısının da lanetlendiği Leheb suresinde malının da kendine fayda sağlamadığ söz konusu edilerek zenginliğini de İslam düşmanlığı için kullandığı vurgulanmıştır. Aynı surede Allah Resûlü'nün (s) Safâ tepesinde sürdürdüğü açıktan tebliğine tepki olarak Ebû Leheb'in ettiği beddua kendisine çevrilerek "Ebû Leheb'in elleri kurusun, kurudu da" 21 denilmiştir.

Allah Resûlü’nün (s) "En yakın akrabanı uyar 22" ilahi emriyle başladığı açıktan tebliğe belki de ilk karşı çıkan ve onun davasını ortadan kaldırmaya bütün imkânlarıyla çalışan Benû Hâşim mensubu yegâne kişi Ebu Leheb olmuştur. Öte yandan Kureyş'in Benû Hâşim'i topluca cezalandırarak Allah Resûlü'ne (s) verdikleri desteği çekmesini sağlamak amacıyla uyguladıkları boykot yıllarında Ebû Tâlib Mahallesi'nden ayrılarak müşriklerin safında yer almıştır. Yaptığı bunca kötülükle yetinmeyen Ebû Leheb, kabile reisi olduğu dönemde putların ve ona tapan atalarının cehennemde olduğunu söyleyen ayetleri ${ }^{23}$ bahane ederek, $\mathrm{Hz}$. Peygamber'i (s) kabile himâyesinden çıartma cüretinde bulunmuştur. (İbn Hişâm, 1992, s. 1/237; İbn Sa'd, 1968, s. 1/211) Bunun üzerine Hz. Peygamber (s) himâye talebiyle Tâif'e gittiyse de aradığını bulamadan geri dönmek mecburiyetinde kalmıştır.

Sonuç olarak Hz. Peygamber; (s) amcas1, dünürü ve komşusu Ebû Leheb'in bunca işkencelerine rağmen hep fedakârlık yapan ve sabreden taraf olmuştur. Bir komşu olarak karısıyla birlikte evinin önüne attığı pislikleri görmezden gelme yoluna gitmeyi tercih etmiştir. $\mathrm{Bu}$ süreçte belli bir süre kendi evinin mevcudiyetine rağmen Safa tepesi sırtlarında yer alan Erkam b. Ebi'l-Erkam'ın evini müslümanlarla bir araya gelme mekânı olarak kullanmıştır. (Balc1, 2016, s.38)

\subsubsection{Hz. Abbas ile İlgili Olanlar}

Hz. Peygamber'in (s) İslam'ın tebliğinde çok önemli katkı sağlayan amcalarından biri Hz. Abbas olmuştur. Onun ne zaman müslüman olduğu hususu net olmasa da her halükarda yeğenine katkı vermekten geri durmadığı ve Hz. Peygamber'in (s) özellikle Mekke dışındaki kabilelerle ilişkilerinde kendisinden istifade ettiği bilinmektedir.

\footnotetext{
${ }^{21}$ Leheb 111/1.

22 eş-Şuarâ $26 / 214$

23 el-Enbiyâ 21/98.
} 
Hz. Abbas, babasının vefatıyla oğlu Ebû Tâlib’e geçen "sikâye" ve "rifâde" görevlerini ağabeyinin maddi durumunun elvermemesi nedeniyle devralmıştır. (İbn Hişâm, 1992, s. 1/120) Öte yandan uluslararası nitelikte ticaret yapma imkânına sahip şehrin önemli tüccarlarından biridir. İşte bu sebeplerden dolayı olsa gerek Hz. Abbas, Hz. Peygamber'in (s) diş bağlantılarında daha çok karşımıza çıkmaktadır. Özellikle Allah Resûlü'nün (s) Medinelilerle yaptığı daha çok siyasi içerikli İkinci Akabe Biat'ında (İbn Hişâm, 1992, s. 1/298; İbn Sa'd, 1968, s. 1/222; Belâzûrî, 1996, s. 1/240; Özaktan, 2017, s. 350) onun başrolde olduğu dikkatlerden kaçmaz. Bununla birlikte Mekke'nin fethinin hemen evvelinde yine sahnede gözüken Hz. Abbas'ın birbirlerinin rakibi durumunda olan şehrin devlet başkanı Ebû Süfyan ile yeğeni ve Medine'nin devlet başkanı Hz. Peygamber'in (s) aralarındaki iletişimin sağlanması ve neticede kan akıtılmadan şehrin teslimi noktasındaki katkıları tarihen sabittir. (İbn Hişâm, 1992, s. 2/ 853; İbn Sa'd, 1968, s. 2/135)

Hz. Abbas'ın ilk müslümanlardan olduğu hususunu doğru kabul edersek, bu noktada Hz. Peygamber'in (s) çok önemli bir strateji izlediği ortaya çıkar. Bu teze göre Hz. Peygamber, (s) müşrik liderler arasında olup bitenlerin özellikle Medine sürecinde kendisine aktarılmasını temin etmek için aralarında belirledikleri stratejiyle amcasının müslüman olduğunu deşifre etmemesini istemiştir. Böylece Hz. Abbas, Allah Resûlü'nün (s) Mekke'deki gören gözü ve işiten kulağı olmuş ve Mekke'nin düşmesine kadar geçen süreçte çok önemli görevler îfâ etmiştir. Bu sürecin sonunda Mekke'nin fethinin hemen öncesinde yine şehrin kan dökülmeden tesliminin sağlanması için şehrin devlet başkanı Ebû Süfyan'ın ikna edilmesinde de etkili olmuştur. (İbn Hişâm, 1992, s. 2/853; İbn Sa'd, 1968, s. 2/135) Bundan sonra artık strateji hedefine ulaştı̆̆ için müslümanlığını gizlemeye de gerek kalmamıştır. Sonuç olarak, Allah Resûlü (s) tarafindan uygulamaya konulan strateji, Kureyş'in kazanılması hedefinin gerçekleşmesinde oldukça önemli katkılar sağlamıştır.

\subsection{Hâşimîler Dışındaki Kureyș Liderleriyle İlgili Stratejileri}

Daha çok açıktan tebliğ başladıktan sonra, başta Ebû Cehil olmak üzere Kureyşli reisler Allah Resûlü'nün (s) davetine icabet etmemekle beraber, her hangi bir tepkisel tavır içine de girmemişlerdir. Onlar açısından tahammül noktasının bittiği yer, nazil olan ayetlerin müşrikleri, atalarını ve putlarını eleştirmesi olmuştur. Diğer bir ifadeyle, merkezinde putların yer aldığı kurulu düzeni alt üst edecek etkiye sahip ayetlerin ${ }^{24}$ nazil olmasıdır. Muhtemelen bu gelişme üzerine konuyla ilgili kendilerince bir çözüm üretmek üzere şehrin karar mercii durumunda olan Dârunnedve'de toplanarak bir kısım kararlar almışlardır. (İbn Hişâm, 1992, s. 1/332) Konuyla ilgili rivayetlerden ve araştırmalardan anlaşıldığına göre bunları; "İtibarsızlaştırma", "Anlaşma Girişimi", "Benû Hâşimi Cezalandırarak Çözüm Bulma" ve "Hz. Peygamber'i (s) Ortadan Kaldırma" (Apak, 2011, s. 165; Bayram, 2019, s. 923-937; Şimşir, 2017, s. 49-53; Y1lmaz, 2019, s. 73-74) olarak tasnif etmek mümkündür. Ancak bu süreçlerin kronolojik olarak tamamen bu tasnife göre cereyan ettiğini söylemek güçtür. Aynı zamanda bu süreçlerin sadece Hz. Peygamber (s) için söz konusu olduğunu, diğer müslümanlara, içinde bulundukları sosyal statüye göre muhtelif şekillerde eziyet edilmeye başlandığını ifade ettikten sonra sözünü ettiğimiz aşamaları detaylandırmaya geçebiliriz:

İlk merhale, başta Allah Resûlü (s) olmak üzere İslam'in ve müslümanların itibarsızlaştırılması için atılan adımlar olmuştur. Onu şairlik, ${ }^{25}$ kâhinlik, ${ }^{26}$ sihirbazlık, mecnunluk ${ }^{27}$ gibi kendisinde olmayan vasıflarla suçlamışlardır. Dahası küçümseyip alay ederek peygamberliği kendisine yakıştıramamışlardır. Onların asıl niyetlerinin öğrenmek değil, bir taraftan Hz. Peygamber (s) ile alay etmek bir taraftan da art niyetlilerin dışındaki insanların zihninde soru işaretleri oluşturarak onların müslümanlar safına katılmalarını önlemek amacında

\footnotetext{
${ }^{24}$ el-Enbiyâ 21/98-100.

25 el-Enbiya 21/5; et-Tûr 52/30.

${ }^{26}$ et-Tûr 52/29.

27 et-Tûr 52/29.
} 
oldukları hiç kuşkusuz Yüce Allah tarafından bilinmekteydi. Belki de bu yüzden sözü edilen ithamlara ${ }^{28}$ ilgili ayetlerde ${ }^{29}$ makul cevaplar verilmiştir.

Kabile reislerinden oluşan Mekke şehrinin oligarşik yönetiminin amac1, (Öz, 2018, s. 53-54) sözünü ettiğimiz tavır ve davranışlarıyla kendilerince mevcut yapıyı korumayı ve bu yapının kendilerine iktisap ettirdiği kazanımları sürdürmektir. ${ }^{30}$ Onlar Allah Resûlü'nün (s) peygamberliğini daha çok Benû Hâşim'in asabiyet kaygısıyla kalkıştığı bir hareket olarak değerlendirdiklerinden belki de kabile çekişmelerinde alışageldikleri tuzaklardan biri olan "itibarsızlaştırma" ile rakiplerini gözden düşürerek kendiliğinden sahadan çekilmesini hedeflemişlerdir. Ancak arkasında Yüce Allah'ın vahiyle destek verdiği taraf, uygulamaya koyduğu stratejilerle onların beklentilerini boşa çıarmayı başarmıştır.

İtibarsızlaştırma çabalarının sonuç vermediği görülünce tüccarlıktan edindikleri alışkanlıkla alışverişte olduğu gibi pazarlığa girişerek bir orta yol bulmaya çalışmışlardır. Hz. Peygamber'in (s) konuyla ilgili pazarlık yapma imkânının olmadığı gerçeğini hala anlayamadıklarından, onunla sıkı bir pazarlığa girişerek Allah Resûlü'nün (s) getirdiği yeni sistemi tabir caizse kurulu düzenin bir aparatı haline getirmeye çalışmışlardır. Bunun için, "bir gün biz seninkine, ertesi gün de sen bizim putlarımıza ibadet et" 31 önerisinde bulunarak, şirk üzere kurulu olan Panteona yeni bir put eklemlemeyi düşünmüş olmalılar. Bu aşamada müşrik liderlerin tuzaklarına karşıllık olmak üzere Hz. Peygamber'in (s) tatbik ettiği stratejileri, "Müşriklerin Pazarlık Önerilerine Karşılık Olanlar", ve "Pasif Direniş Çabalarıyla İlgili Olanlar" şeklinde tasnif etmek mümkündür.

\subsubsection{Müşriklerin Pazarlık Önerilerine Karşılık Olanlar}

Kur'an-1 Kerim'de “Az kalsın, sana vahyettiğimizden başkasını bize iftira edesin diye seni bile fitneye düşüreceklerdi ve o takdirde seni dost edineceklerdi. Eğer biz sana sebat vermemiş olsaydık, sen onlara birazcık meyledecektin. Ve o takdirde biz sana mutlaka hayatın da ölümün de sıkıntılarını kat kat tattırırdık, sonra bize karşı kendine hiçbir yardımcı bulamazdın," 32 ayetlerinin nüzûl sebebi olarak tefsirlerimizde bazı hadiselerden bahsedilir. Hz. Peygamber (s) Haceru'l-Esved'i selamlamak istediğinde, Kureyş önderleri kendisine engel olarak "Gelip bizim tanrılarımıza el sürmedikçe bırakmayız" dedikleri, bunun üzerine Allah Resûlü'nün (s) kalbinden "Acaba gönülden istemeyerek bunların dediklerini yapsam da bana engel olmasalar" diye geçtiği rivayet edilir. (Ateş, 1988, s. 7/238) Bu ayetin nüzûl sebebinin, sözünü ettiğimiz rivayetlerin dışında Sakîf heyeti ile ilgili olduğunu gösteren rivayetler varsa da, bunlar kronolojik olarak sorunlu ${ }^{33}$ olduğu için üzerinde durmağa değer bulmuyoruz.

$\mathrm{Bu}$ ve buna benzer ayetlerle ilgili Süleyman Ateş şu değerlendirmeyi yapmaktadır: "Uzun süre muhalefetle karşılaşan Allah Resûlü'nün (s) müşrikleri davasına inandırabilmek için, talep ettikleri bazı ödünleri vermeyi düşündüğünü anlamak mümkündür. Çünkü $\mathrm{Hz}$. Peygamber (s) de bir insandır. Müşriklerin şiddetli itirazları ve alay etmeleri karşısında zaman zaman son derece üzüldüğü de birçok ayetten anlaşılmaktadır. Demek ki, muhaliflerine davasını kabul ettirebilmek için onların bazı önerilerini kabul etmeyi düşünmüş, fakat Allah onun kalbini korumuş, müşriklere hiçbir taviz vermeden kendisine verilen vahyi tebliğe devam etmiştir." (Ateş, 1988, s. 7/238)

Mekkeli müşrik liderlerinin Allah Resûlü (s) ile pazarlığa giriştikleri süreçte vukû bulduğu iddia edilen hadiselerden biri de "Kuğular" anlamına gelen Garânîk hadisesidir. Rivayete göre Hz. Peygamber (s) Necm suresinin "Gördünüz değil mi Lât'1 Uzzâ'y1 ve bir diğerini, üçüncüsü olan Menât' 1 " ayetlerinden ${ }^{34}$ hemen sonra "Onlar yüce kuğulardır, muhakkak

\footnotetext{
${ }^{28}$ el-En'am 6/8; el-Hûd 11/12; el-Hicr 15/7; el-Furkan 25/7 vd.

${ }^{29}$ el-İsrâ 17/95; el-En'am 6/111 vd.

${ }^{30}$ el-Kasas $28 / 57$.

31 el-Kâfirûn 109/1-6)

32 el-İsrâ 17/73-74.

${ }^{33}$ Sakîf heyetinin gelişi hadisesi risâletin Medine dönemiyle ilgili iken bahsi geçen olay Mekke döneminde ortaya çıkmıştır.

${ }^{34}$ Necm 53/19-20.
} 
ki, şefaatleri umulur" mealinde iki cümle yerleştirmiştir. Daha sonra bu problem Hac suresinin $52,53,54$ ve 55. ayetleriyle vuzuha kavuşturulmuştur. Her ne kadar sorun açıklığa kavuşturulmuşsa da bu gelişme, Habeş muhacirlerinin en azından bir kısmının geri dönmesine neden olmuştur. (İbn Sa'd, 1968, s. I/205) Konuyla ilgili ayetlerin tefsiri için müfessirler ve Hz. Peygamber'in ismeti sadedinde de kelam âlimleri uzun uzadıya tartışmışlar ve müstakil eserler dahi yazmışlardır. İbn Hişâm'ın eserine almadığı ancak nakillerini genellikle kendisine dayandırdığı İbn İshâk'ın ana hatlarıyla (İbn İshâk, 1978, s. 158) ve hicri 3. asır müelliflerinden İbn Sa'd ve Vâkıdî'nin ayrıntılı olarak eserine aldığı hadise, anlaşıldığı kadarıyla müşrik liderlerin bir oldubittiye getirerek Hz. Peygamber'i (s) istedikleri noktaya getirme çabası gibi gözükmektedir. Nitekim bir kısım âlimler bahsi geçen cümlelerin şeytani nitelikli bir kısım insanlar tarafindan ortaya konulduğunu iddia etmektedirler. (Cerrahoğlu, 1996, s. 13/361-366)

Müşrik liderlerin Hz. Peygamber (s) ile yaptıkları pazarlığa yönelik hadiselerden biri de Abdullah b. Ümmü Mektûm ile ilgili olandır. Allah Resûlü (s) Mekke'de Kureyş’in ileri gelenlerinden Utbe b. Rebia, Ebû Cehl, Abbas b. Abdülmuttalib'e davasını anlatmaya çalıştığı esnada daha önce müslüman olmuş Abdullah b. Ümmü Mektûm gelerek "Ey Allah'ın elçisi, Allah'ın sana öğrettiklerinden bana da öğret" diye talepte bulunarak sözünü keser. Bir miktar bekleyip cevap gelmeyince yeniden aynı şekilde tekrar eder. Bunun üzerine Allah Resûlü'nün (s) yüzünde sözünün kesilmesinden dolayı bir hoşnutsuzluk belirir, dahası yüzünü bahsi geçen müşriklerden yana çevirir ve onlarla ilgilenmeğe devam eder. (İbn Hişâm, 1992, s. I/245) Bu hadise, Abese suresinin nüzul sebebi olarak gösterilir. Konuyla ilgili ayetlerin meali şöyledir: "Yüzünü astı ve döndü, âmâ geldi diye. Ne bilirsin belki o arınacak? Veya öğüt dinleyecek de öğüt kendisine yarayacak. Kendisini müstağni görüp tenezzül etmeyene gelince sen ona yöneliyorsun, onun arınmamasından sana ne? Fakat koşarak sana gelen saygı duyarak gelmişken sen onunla ilgilenmiyorsun." 35

Hz. Peygamber'e (s) inananlardan bir kısmı köle, fakir, mevâlî gibi toplumun daha alt tabakasını teşkil eden kimselerden oluşuyordu. Mekke müşriklerinin önde gelenleri toplumlarındaki statülerinden dolayı Allah Resûlü'nün (s) böyle kimselerle ilgilenmesini, onlarla bir arada bulunmasını yadırgarlardı. Bir gün Hz. Peygamber (s) Süheyb b. Sinan erRûmî, Ammar b. Yasir, Bilal-i Habeşî, Habbab b. Eret gibi müslümanlarla birlikte iken müşrik önde gelenleri ona, "Sen kavminden vazgeçtin de bunlara $\mathrm{m} 1$ razı oldun? Biz bunlara $\mathrm{m} 1$ tabi olacağız? Onları yanından kov, o zaman belki de biz sana uyarız," biçiminde istekte bulununca Allah Resûlü, (s) "Ben, mü'minleri kovan bir kimse değilim” diye cevap vermiştir. Bunun üzerine müşrikler "O halde biz geldiğimiz zaman onları yanından uzaklaştır, biz kalkıp gittiğimiz zaman dilersen onları yanında oturt" diye mukabelede bulununca şu ayetler nazil olmuştur: "Sabah akşam Rablerine sırf onun rızasını dileyerek dua edenleri kovma! Onların hesabından sana bir sorumluluk, senin hesabından da onlara bir sorumluluk yok ki, onları kovup da zalimlerden olasin". ${ }^{36}$

Sonuç olarak, müşrik liderlerin ticari hayatta muhtelif şekillerdeki pazarlık ve emr-i vaki oluşturma taktiklerini Allah Resûlü (s) üzerinden İslam daveti için de uygulamaya çalıştıkları anlaşılmaktadır. Müşrikler, aynı zamanda bir tüccar da olan Allah Resûlü'nün (s) bir şekilde ikna edilebileceğini hatta yeni gelen bu dini kendi sistemlerinin daha da geliştirilmesine katkı sağlamak için kullanmayı bile düşünmüş olmalıdırlar. Ancak onları çok iyi tanıyan ve dillerini iyi bilen Hz. Peygamber (s) vahyin rehberliğinde onların tuzaklarına düşmeden ve tebliğ sürecine de halel getirmeden "Kızım sana söylüyorum, gelinim sen anla" söylemindeki türden taktiklerin de içinde olduğu stratejiyle süreci atlatmayı başarmıştır. Buna göre vahyin koruma altında olduğu, ${ }^{37}$ elçinin hiçbir şekilde ilahi öğretilere ekleme ve çıkarma yapamayacağ $1^{38}$ Allah Resûlü üzerinden tehdit motifleriyle müşriklere iletilmiştir. Öte yandan

\footnotetext{
${ }^{35}$ el- Abese 80/1-10.

36 el-Enâm 6/52.

${ }^{37}$ el-Hicr 15/9;el-Kiyamet 75/17.

38 el-Hâkka 44-47; el-İsrâ 17/73-74; el-Hâc 22/52-55.
} 
Garânîk hadisesinde olduğu gibi yanlış anlamalar veya emr-i vakiler zaman geçmeden düzeltilerek ilahi emanetin oldubittilerle sabote edilmesi engellenmiş ve duruma vaziyet edildiği müşriklere ima edilmiştir. Böylece Hz. Peygamber (s) bu süreçte asla ikircikli bir tavır sergilemeden görevini yerine getirmeyi başarmıştır.

\subsubsection{Pasif Direniş Çabalarıyla İlgili Olanlar}

Hz. Peygamber'in (s) risâletinin Mekke sürecinde müşriklerin muhtelif şekillerdeki saldırılarına karşı müslümanların izlediği stratejilerden birisi de "Pasif direniş" olarak adlandırılabilir. Aslında bu ismi oluşturan iki kelime anlam bakımından birbiriyle tamamen zıttır. Çünkü bir yönüyle pasif olmayı ama bir başka yönüyle de olabildiğince aktif olmayı gerektirmektedir. $\mathrm{Bu}$ anlam karmaşasını süreçte olup bitenlerden yola çıkarak şöyle vuzuha kavuşturmak mümkündür. Gidişata bakıldığında müşriklerin her türlü saldırılarına karşı müslümanların pasif bir tavır içerisinde oldukları görülmektedir. Buna karşın benimsedikleri yeni din ile ilgili olarak asla tavizkar olmadıkları, olabildiğince direniş içinde oldukları anlaşılmaktadır.

$\mathrm{Bu}$ stratejiyi müslümanların Mekke sürecinin tamamında uyguladıkları her hangi bir karşı saldırıya geçmedikleri görülmektedir. Ayetlerde müşriklerin yaptıklarına karşılık olarak müslümanların sabretmeleri ${ }^{39}$ ve Hz. Peygamber' in liderliğinde birbirlerine kenetlenmeleri ${ }^{40}$ istenmiştir. Buna göre müslümanlar Dâru'l-Erkâm'da, Habeşistan hicretiyle ve boykot yıllarında Ebu Talib mahallesinde bu stratejiyi tatbik etmişlerdir. Şimdi bunları stratejinin izahı sadedinde sırasiyla ele almaya çalışalım.

Dâru'l-Erkâm aslında ilk müslümanlardan Erkam b. Ebi'l-Erkam el-Mahzûmîye ait bir evdir. Ancak burası Risalet'in çok erken bir döneminde ${ }^{41} \mathrm{~Hz}$. Peygamber liderliğindeki müslümanlara tahsis edilmiş olduğundan, tebliğin ilk yıllarındaki atmosferin anlaşılması açısından önem arz etmektedir. Safa tepesinin eteklerinde yer alan bu mekânı Allah Resûlü Kâbe'nin hareminde yer alması, hac ve umre için gelenlerle temas imkânı olması gibi nedenlerle seçmiş olmalıdır. (Köksal, 1993, s. 520) Bu süreçte müslümanlar Kâbe'de cemaatle namaz kılmak, sesli olarak Kur'an okumak gibi özellikle müşrik liderleri tedirgin edeceği varsayılan tavır ve davranışlardan uzak kalmaya çalışmışlardır. Hz. Peygamber (s) nazil olan ayetleri okuyarak müslümanları irşat etmiş, onlara cemaatle namaz kıldırmış, yeni müslümanların ihtidası ve müslüman cemaat ile kaynaşmaları da burada temin edilmiştir. Bu süreçte müslümanlar, müşriklerin saldırılarına karşı pasif olmuşlarsa da dinlerine ve müslüman kardeşlerine sımsıkı sarılmışlardır. Böylece bir taraftan tebliğ faaliyetlerini devam ettirme imkânı buldukları gibi bir taraftan da müslümanlığı benimseyenlerin yetiştirilmesi sağlanmıştır. ${ }^{42}$

Risâletin 5. y1lına gelindiğinde Hz. Hamza gibi önemli isimlerin müslümanlığ benimsemesi, müşrik liderleri iyice endişeye sevk etmiş olmalı ki, kabile yönetimleri aracılığıyla müslümanlara baskıyı daha da artırırlar. Bu çerçevede onlardan himâyeyi kaldırdıkları (Apak, 2017, s. 31; Öztürk, 2001, s. 9) gibi giderek artan oranda bask1 da uygulamaya başlarlar. $\mathrm{Bu}$ durum bir taraftan müslümanların dayanılmaz eziyetlere maruz kalmalarına neden olduğu gibi, zaten bir avuç olan müslümanların dinden dönmelerine de neden olabileceği endişesiyle olsa gerek, Hz. Peygamber'i (s) soruna bir çözüm bulmaya sevk etmiştir. ${ }^{43}$ İşte müslümanların iki aşamalı olarak yaptıkları ilk hicretlerinin arka planı kısaca bu şekildedir. Risâletin 5/6. yılının Recep ayında gerçekleşen ilk aşamada 11 erkek 4 kadın (İbn

\footnotetext{
${ }^{39}$ Taha 20/130; Kâf 50/39; el-Kalem 68/48 vb.

${ }^{40}$ el-Hicr 15/88; eș-Şuarâ 26/215.

${ }^{41}$ Hz. Peygamber'in Dârülerkam'a geliş tarihi nübüvvetin 4. yılı olarak kabul edilirse de bu doğru değildir. Erkam b. Ebü’lErkam'ın ilk müslümanlar arasında yer almasından dolayı bu tarihi bi‘setin 1. yılı, hatta bu yılın ilk ayları olarak kabul etmek gerekir. Hz. Peygamber, nübüvvetin 6. yılı Zilhicce ayında Ömer'in müslüman olmasından sonra Dârülerkam'dan ayrılmıştır. Geniş bilgi için bkz. (Köksal, 1993)

${ }^{42}$ Hicr 15/88; Suarâ 26/215.

${ }^{43}$ Habeş hicretlerinin sebepleriyle ilgili olarak bkz.Levent Öztürk, Etiyopya'da İslamiyet I, İstanbul, 2001, s. 55-66; Adem Apak, "Habeşistan Hicreti Üzerine Mülahazalar," Siyer Arastırmaları Dergisi, 2 (2017): 31-33.
} 
Hişâm, 1992, s. I, 214) ve ertesi y1l Cafer b. Ebi Tâlib'in rehberliğinde gerçekleşen ikinci aşamada ise 82 erkek ve 18 kadın Habeşistan'a hicret etmiştir. (İbn Hişâm, 1992, s. 1/245; İbn Sa'd, 1968, s. 1/205; Vâkı1î, 1984, s. II/683)

Habeşistan hicreti de, müşriklerin müslümanlara uyguladıkları her kabilenin kendi mensuplarını İslam'dan uzak tutma tuzağına karşı müslümanların tatbik ettikleri karşı stratejilerdendir. Buna göre müslümanlar, müşriklere karşı saldırıya geçmeyerek pasif olsalar da, inançlarında direnmeye ve muhataplarına meydan okumayı sürdüreceklerdir. Sığınma talebinde bulundukları Habeşistan ve adil kralı Necaşi, Kureyş riyasetiyle mukayese edildiğinde, hem daha üst statüde, aynı zamanda bir şekilde Kureyş'in etkisinde olan bir yap1 değildir. Bu yüzden daha üst statüdeki bağımsız bir devlet tarafından müslümanların kabul edilmiş olması, müslümanların Kureyş'in tuzağını boşa çıkarması ve onlara bir çeşit meydan okuma olarak da değerlendirilebilir. Bu durum Kureyş'i oldukça rahatsız etmiş olmalı ki, çok değerli hediyelerle elçi heyeti göndererek müslümanların iade edilmelerini talep etmiş̧lerse de Necâşî isteklerini geri çevirmiştir. Öte yandan Habeşistan'a hicret eden müslümanların kendi kabilelerinden çekilip alınması ve Allah Resûlü'nün (s) önerdiği oldukça uzak bir mahalle hicret ediyor oluşları, müslümanların lideri konumundaki Hz. Peygamber'in (s) rakipleri olan reislere karşı başka bir meydan okuması olarak değerlendirilebilir. Müslümanların sayıca oldukça az oldukları risâletin 5. yılında bu derece önemli meydan okumalar, Kureyş müşriklerini oldukça tedirgin etmiş olmalı ki, müslümanlara tatbik etmeye çalıştıkları tuzaklar her geçen gün artarak devam edecektir.

Ebû Tâlib üzerinden Hz. Peygamber'i (s) vazgeçirme çabaları sonuç vermeyince müşriklerin başvurdukları tuzaklardan biri de boykot hadisesini hayata geçirmeleri olmuştur. Böylece Hâşimilerin ve müttefiklerinin Kureyş'in diğer kollarıyla her türlü iletişimini keserek cezalandırmayı planlamışlardır. (İbn Hişâm, 1992, s. 1/235; İbn Sa'd, 1968, s. 1/208) Uyguladıkları bu yaptırım ile "İçinizden Kureyş geleneklerine aykırı hareket eden Abdullah oğlu Muhammed'i cezalandırmadığınız gibi arka çıktığınız için hepinizi cezalandırıyoruz" şeklinde bir mesaj iletmeye çalışmışlardır.

Anlaşıldığ1 kadarıyla Hâşimîlerden hiç birisinin Allah Resûlü'ne (s) gelerek "Çektiğimiz bunca sıkıntıları senin yüzünden yaşıyoruz" şeklinde bir başa kakma tavır ve davranışını sergileyen olmamıştır. Tersine kendi kabilelerinden olan Allah Resûlü'nü bu süreçte daha sıkı bir şekilde korumaya almışlardır. Böylece kabile mensuplarının dayanışmasını zaafa uğratıcı bir durum ortaya çıkmadığı gibi birbirlerine daha da kenetlenmişlerdir. (İbn Hişâm, 1992, s. /1235; İbn Sa'd, 1968, s.1/208) Sonunda böyle bir cezalandırma şeklini doğru bulmayanların girişimleriyle maksat hâsıl olamadan uygulamaya çalıştıkları tuzak yine başarıya ulaşamamıştır.

\subsection{Kureyş’i Diğer Araplar Üzerinden Çözme Stratejileri}

Hicaz bölgesindeki kabile gerçeğini çok iyi bilen Allah Resulü, (s) stratejisini Kureyş’i kazanma üzerine inşa etmiştir. Çünkü bölge kabileleri üzerindeki Kureyş’in belirleyici oluşu, onu böyle davranmaya itmiştir. Bu çerçevede önce Taif, sonra Adnani kökenli civar Arap kabileleri ve sonunda da Kahtani kökenli Evs ve Hazrecli kabileler üzerinden muhtelif adımlar atmıştır. Bunlardan sonuncusu başarılı olmuş önce Hudeybiye musalahası ve ardından gelen Mekke'nin fethiyle de başarıya ulaşmıştır.

\subsubsection{Kureyş’i Tâif Üzerinden Çözme Stratejisi}

Hz. Peygamber (s), gizli tebliğg, açıktan tebliğ ve muhtelif şekillerde kabile reislerini kazanmaya yönelik girişimlerine rağmen, mensuplarını birbirine kenetlemiş kabile sarmalına sirayet etme imkânını elde edememiştir. En azından himâyesini elde etmiş olduğu kendi kabilesinin desteğini de önce Ebû Tâlib'in vefatı sonra da Ebû Leheb'in himâyesini kaldırmasıyla kaybetmiş oldu. Bu arada hamisi Ebû Tâlib'in vefatının ardından, hayat arkadaşı ve manevi destekçisi olan eşi Hz. Hatice'yi de yitirmiştir. (İbn Hişâm, 1992, s. 1/280) Bütün bu 
kayıpların yanında Mekke yönetim merkezi Dârunnedve'nin organizesiyle başını Ebû Cehil'in çektiği oligarşik yapının mensupları olan müşrik liderler, İslam'ın nurunu ve başta $\mathrm{Hz}$. Peygamber (s) olmak üzere mü'minlerin etkinliğini kırmak için ellerindeki bütün imkânları seferber ediyorlardı. Şehirde müslüman olanların güvenliği sıkıntılı olduğu için inananların çoğunluğu da Habeşistan'a hicret etmiş durumdaydı. Sözünü ettiğimiz bunca olumsuz koşullara rağmen Allah Resûlü'nün (s) Tâif'e giderek yeni bir çıkış yolu arayışına girdiğini görüyoruz. ( İbn Hişâm, 1992, s. 1/282-283; İbn Sa'd, 1968, s. /1210; Belâzûrî, 1996, s. 1/227)

Mekke'nin yazlık mahalli de olan Tâif şehri mekân olarak en yakın yerleşim yeri mesabesindeydi. Şehrin sakinlerinin ürettiği tarım ve hayvancılı̆̆a dayalı ürünlerin pazarlama işini Kureyş tüccarları üstlenmişti. Bu şehirde oturan Sakîf kabilesi, Kureyşlilerin de içerisinde yer aldığı Adnânî Araplarını oluşturuyorlardı. Bütün bu sebeplerden dolayı Tâifliler ile Mekkeliler çok sıkı işbirliği içindeydiler. Belki de Allah Resûlü (s), sözünü ettiğimiz yakın ilişkilerinden dolayı Sakîfli liderlerin de desteğini alarak Kureyş düğümünün çözülmesini de varsaymış olabilir. Allah Resûlü sözünü ettiğimiz avantajların getirisini hedefleyerek Sakîf kabilesinin ileri gelenlerinden Amr b. Umeyr'in üç oğlu Mesûd, Habib, Abdüyâlîl gibi şehrin ileri gelenlerini İslam'a davet etmek ve Mekkelilere karşı himâye talep etmek üzere yola çıkmıştır. ( İbn Hişâm, 1992, s. 1/82-283; İbn Sa'd, 1968, s. 1/210; Belâzûrî, 1996, s. 1/227)

Kureyş müşrikleriyle Hz. Peygamber arasındaki gelişmelerin farkında olan Sakîfliler, geleneksel himâye anlayışında "Talep eden düşmanınız da olsa himâye verilir" ilkesine (Bozkurt, 1998, s. 18/56; Çavuş, 2018, s. 100) rağmen Kureyş’ten çekindikleri için Allah Resûlü'nün (s) talebine müspet cevap verememişlerdir. Dahası Hz. Peygamber'in (s) "Kureyşlilere karşı işbirliği teklifim deşifre edilmesin" talebini bile yerine getirme cesaretini gösterememişlerdir. Bununla da yetinmeyerek asırlarca alınlarında bir leke olması pahasına kendilerinden himâye talep eden zor durumda olan bir insanı taşlatma talihsizliğini göstermişlerdir. Bunun izahı "size isyan eden bir Kureyşliye biz de sahip çıkmayız" mesajının Mekkelilere iletilmesinden başka bir şey değildir. Muhtemelen Kureyş korkusu o kadar çok zihinlerinde yer etmiş olmalı ki, himâye talebini reddetmek müttefiklerine karşı bir iyi niyet göstergesi olarak yeterli olmaz diye düşünerek konuyla ilgili niyetlerinin açık izharı olarak ayak takımı insanlara taşlatma kabalığını sergilemek durumunda olmuşlardır. (İbn Hişâm, 1992, s. 1/282-283; İbn Sa'd, 1968, s. 1/210; Belâzûrî, 1996, s. 1/227)

Saldırganlar karşısında zor durumda kalan Allah Resûlü (s) ve yanı başındaki evlatlığı Zeyd b. Harise, atılan taşlardan kendilerini kurtarmak için Utbe ve Şeybe kardeşlerin üzüm bağına sığınmak zorunda kalmışlardır. (İbn Hişâm, 1992, s. 1/282-283; İ̉nn Sa'd, 1968, s. 1/210; Belâzûrî, 1996, s. 1/227;) Geleneğe aykırı olarak taşkınlık yapanların bu noktada taş atmayı kesmiş olmaları, kişisel mülkiyete saygıdan çok yine Kureyş korkusunu akla getirmektedir. Bu arada Tâiflilerin kendilerine yaranma gayreti içinde oldukları Kureyş aristokratlarından olan Utbe ve Şeybe kardeşler, Allah Resûlü'ne (s) Sakîflilerden himâye talep etmek zorunda birakanlardan bir kesim olan Benû Ümeyye'ye mensupturlar. Onlar, kabile özelinde Hz. Peygamber'i (s) istedikleri noktaya getirmek için zorlarken bu örnekte olduğu gibi başka kabileler söz konusu olduğunda onlara karşı kendilerinden olan kabile mensuplarıyla kenetlendikleri görülmektedir. Bu durum, "zalim de olsa kardeşine yardım et" (Apak, 2017, s. 88) şeklinde tezahür eden Kureyş asabiyetinin göstergesidir.

Sonuç olarak Allah Resûlü'nün (s) uygulamaya çalıştığı, Kureyş’e rağmen Sakîflilerin desteğiyle tebliğ faaliyetini sürdürme stratejisi hayata geçirilememiştir. Bunun üzerine $\mathrm{Hz}$. Peygamber (s) Mekke'ye geri döndüyse de ancak Benû Nevfel'den Mut'im b. Adi'nin verdiği himâye (İbn Hişâm, 1992, s. 1/255; İbn Sa'd, 1968, s. 1/215) ile şehre girme imkânı elde edebilecektir.

\subsubsection{Kureyş’i Çevre Kabileler Üzerinden Çözme Stratejisi}

Hz. Peygamber (s) açıktan davet sürecinde yakın çevreden başlamış, giderek uzak akrabalara ve sonuçta bütün insanlığa kadar ulaşmayı hedefleyen bir strateji izlemiş̧ir. 
Bu süreçte Kureyşli reislerin en çok rahatsız olduğu adım, Allah Resûlü'nün (s) Kureyş dışındaki çevre kabilelere davasını anlatmaya başlamasıdır. Onların rahatsız olmalarının sebebi, rasyonel olarak izahı mümkün olmayan, bir kurgu üzerine kurulu ve merkezinde Kâbe'nin, putların, fal okları gibi diğer aparatların yer aldığ 1 kurulu düzenlerinin alt üst olmas1 korkusudur. Bu düzenin temelinde, kutsal mabed Kâbe üzerinden sağladıkları Kureyş’in üstünlüğü anlayışı yer almaktaydı. Onlar çevre kabileler üzerinde kurdukları bir çeşit hegemonya ile onları bu anlayışa inandırarak hem uluslararası ticaret yollarında güvenlik elde etmekte hem de yakın ve uzak pazarlardan getirdikleri ticari metaları satarak, çok karlı bir ticareti ${ }^{44}$ sürdürmekteydi. (Hamidullah, 2000, s. 22/63-64; Y1lmaz, 2019, s. 67; Yüksel, 1994, s. 309-310) Dolayısıyla Hz. Peygamber' in (s) çevre kabilelere açılması, onların her şeyden değerli saydıklarını itibarlarını kaybettirirken, ekonomik kayıp da demekti. Bundan dolay1 müslümanlara "Sizinle beraber doğru yolu tutarsak, kendi yurdumuzdan koparılıp çıkarılırız" dediler.

Mekkeli müşriklerin bütün engelleme çabalarına rağmen $\mathrm{Hz}$ Peygamber (s) özellikle hac mevsiminde çevre kabilelere davasını yaymaya çalışmıştır. Bu süreçte Tufeyl b. Amr edDevsî (İbn Hişâm, 1992, s. 1/255-258) gibi ferdi düzeyde kazanımlar söz konusu olmuşsa da, Kureyşlilerden reis/şeyh düzeyinde bir katılım sağlanamamıştır. Allah Resûlü'nün (s) Tâif dönüşünden sonra bu stratejisini daha da hızlandırdığ1 görülür. Hz. Peygamber (s) Mekke’ye gelen çok sayıda kabileye davet götürmüşse de bunlar genellikle Kureyş’ten çekindikleri için ilâhi çağrıyı reddetmişlerdir. Bunu göze alabilen tek kabile Benû Âmir b. Sa'saa olmuşsa da, onlar da sağlayacakları destek karşılığında iktidarın kendilerinde olmasını şart koşunca Allah Resûlü (s), "İktidar Allah'ın elindedir, O dilediğine verir" deyince, onlar da destek sağlamaktan imtina etmişlerdir. (İbn Hişâm, 1992, s.1/286; İbn Sa'd, 1968, s. 1/216; Belâzûrî, 1996, s. 1/237)

Bundan sonra Hz. Peygamber (s) Medineli Hazrec mensupları ile görüşerek (İbn Hişâm, 1992, s. 1/298-310; İbn Sa'd, 1968, s. 1/221-223) onlardan beklediği desteği elde etmeyi başaracaktır. Böylece Kureyş'in Kahtânî kökenli Medine'ye sığınmış Arapların desteğiyle çözülmesi stratejisi devreye sokulacaktır. Bu süreç adım adım geliştirilerek nihayet Mekke'nin fethiyle başarıya ulaştırılacaktır. Sözünü ettiğimiz sürecin Medine ayağı ise bir makale boyutunu aşacağından başka bir çalışmanın konusu olarak ele alınacaktır.

\section{Sonuç}

Allah Resulü (s) görev yaptığı süre içinde bir kısım engellemelerle karşılaşmıştır. Bunları bertaraf etmek ve hedefine ulaşabilmek için vahiy destekli çeşitli stratejiler tatbik etmek zorunda kalmıştır. Bunları; Haşimilerle İlgili Olanlar, Haşimiler Dışındaki Kureyş Liderlerle İlgili Olanlar ve Kureyşi Çevre Kabileler Üzerinden Kazanma Amacına Yönelik Olanlar şeklinde 3 başlık altında ortaya koyduk. Hz. Peygamber (s) tarafindan tatbik edilen stratejilerin nirengi noktasını öncelikle Kureyş kabilesinin kazanılması oluşturmuştur. Muhtemelen civar kabilelerin kendilerini Kureyş'e göre konumlandırması uygulaması, Allah Resûlü'nü (s) böyle bir tercihte bulunmaya sevk etmiş olmalıdır. Bunun için öncelikle Allah Resûlü, (s) yakın akrabalarının ait olduğu Benû Hâşim mensuplarını kazanmaya çalışmıştır. Akabinde Kureyş'in diğer kollarına yönelerek ilâhî çağrıyı takdim etmiştir. Bundan sonra da dini veya ticari nedenlerle Mekke şehrine gelen civar kabilelere yönelmiştir. Bunlardan Yesrib şehrinde ikamet eden Evs ve Hazrecliler davete kabile bazında olumlu cevap vermişlerdir. Böylece İslam daveti için yeni bir sayfa açılmış olacaktır. Medine'ye hicretin akabinde arkasına devlet gücünü de alan Hz. Peygamber, Kureyş'i kazanma önceliğini hep ön planda tutmuştur. Bedir zaferi ve Hudeybiye musalahası ile elde edilen nispî başarı Mekke'nin fethiyle taçlanacaktır. Artık Kur'an'ın son nazil olan Nasr suresinde ifadesini bulan “Akın akın Din'e girdiklerini görürsün" ${ }^{46}$ aşamasına gelinmiştir. İslam da'vetinin Mekke sürecinde tatbik edilen stratejilerin

\footnotetext{
${ }^{44}$ el-Kureys 106/1-2

${ }^{45}$ el-Kasas 28/57.

${ }^{46}$ en-Nasr 110/2.
} 
de katkısıyla, bütün engellemelere rağmen müslümanların sayıları her geçen gün biraz daha artmıştır. Aynı zamanda Medine ve sahâbe dönemindeki gelişmeleri yönlendirecek çekirdek kadronun vücuda getirilmesi sağlanmıştır. Gerek Medine döneminde ve gerekse sahâbilerin hayatta olduğu sonraki dönemlerde elde edilen başarılar, sözünü ettiğimiz stratejilerin ne derece isabetli bir şekilde kurgulandığını ortaya koyan önemli göstergelerdir.

\section{Kaynakça}

Algül, H. (1998). Hilfü'l-Mutayyebîn. Türkiye diyanet vakfı İslâm ansiklopedisi (ss. 32-33). İstanbul: TDV Yayınları.

Apak, A. (2001). İslam öncesi dönemde Mekke idare sistemi ve siyasetinin oluşumu. Uludă̆ Üniversitesi İlahiyat Fakültesi Dergisi, 10(1), 177-194.

Apak, A. (2004). Asabiyet ve erken dönem İslam siyasi tarihindeki etkileri. İstanbul: Düşünce Kitabevi.

Apak, A. (2011). Ana hatlarlyla İslam tarihi 1 (Hz. Muhammed (SAV)dönemi). İstanbul: Ensar Yayınları.

Apak, A. (2017a). Habeşistan hicreti üzerine mülahazalar. Siyer Arastırmaları Dergisi, (2), 320.

Apak, A. (2017b). Kabile asabiyetinin mahiyeti üzerine değerlendirmeler. Íslam Tarihi Araştırmaları Dergisi, 2(1), 76-91.

Ateş, S. (1988). Yüce Kur'ân'ın çağdaş tefsiri. İstanbul: Yeni Ufuklar Neşriyat.

Avc1, C. (2010). Şeyh. Türkiye diyanet vakfi İslâm ansiklopedisi. (ss. 49). İstanbul: TDV Yayınları.

Azimli, M. (2015). Cahiliyye'yi farklı okumak. Ankara: Ankara Okulu.

Balc1, İ. (2016). Hz. Peygamber ve namaz. Ankara: Ankara Okulu.

Bayram, E. (2019). Mekke müşriklerinin nübüvvet karşısındaki tutum ve davranışları. MANAS Sosyal Araştırmalar Dergisi, 8(1 (Ek Say1)), 919-939.

Belâzûrî, (279/892). (1996). Ensâbu'l-Eşrâf. (S.-R. Zekkar-Zirikli, Ed.). Beyrut: Dâru'l-Fikr.

Boynukalın, M. (2011). Tebliğ. Türkiye diyanet vakfi İslâm ansiklopedisi (ss. 218-219). İstanbul: TDV Yayınları.

Bozkurt-Küçükaşc1, N.-M. S. (2003). Mekke. Türkiye diyanet vakfi İslâm ansiklopedisi (ss. 555-563). İstanbul: TDV Yayınları.

Bozkurt, N. (1998). Himâye. Türkiye diyanet vakfi İslâm ansiklopedisi (s. 56). İstanbul: TDV Yayınlar1.

Çağrıcı, M. (1994). Da'vet. Türkiye diyanet vakfi İslâm ansiklopedisi (ss. 16-17). İstanbul: TDV Yayınları.

Çavuş, L. (2018). Mekke'de Hz. Muhammed'in (sav) muhalefeti. Milel ve Nihal: İnanç, Kültür ve Mitoloji Araştırmaları Dergisi, 15(2), 84-107.

Çelikkol, Y. (2003). İslam öncesi Mekke. Ankara: Ankara Okulu.

Cerrahoğlu, İ. (1996). Garânîk. Türkiye diyanet vakfi İslâm ansiklopedisi (ss. 361-366). İstanbul: TDV Yayınları.

Cevad Ali. (1993). el-Mufassal fí tarihi'l-Arab kable'l-İslam. Beyrut.

Demircan, A. (2018). İslam öncesi arap yarımadasının dini, siyasi, sosyokültürel ve ekonomik tarihi. M. Şeker (Ed.), İslam Tarihi ve Medeniyeti içinde (ss. 107-158). İstanbul: Siyer 
Yayınlar1.

Fayda, M. (1995). Fetih. Türkiye diyanet vakfi İslâm ansiklopedisi (ss. 467-470). İstanbul: TDV Yayınlar1.

Güç, A. (2007). Putperestlik. Türkiye diyanet vakfi İslâm ansiklopedisi (ss. 365-368). İstanbul: TDV Yayınları.

Hamidullah, M. (1998). Hilfü'l-Fudûl. Türkiye diyanet vakfi İslâm ansiklopedisi (ss. 31-32). İstanbul: TDV Yayınları.

Hamidullah, M. (2000). Îlâf. Türkiye diyanet vakfi İslâm ansiklopedisi (ss. 63-64). İstanbul: TDV Yayınları.

Hitti, P. K. (1989). Siyasi ve kültürel İslam tarihi. (S. Tuğ, Çev.). İstanbul: Boğaziçi Yayınları.

İbn Hişâm, (218/833). (1992). es-Sîretü'n-Nebeviyye. (S. Zekkar, Ed.). Beyrut: Dâru'l-Fikr.

İbnü'l-Kelbî, (204/819).1969. Putlar kitabı, (Beyzâ Düşüngen, Çev.)

İbn İshâk, (151/768). (1978). Sîretü İbn İshâk. (S. Zekkar, Ed.). Beyrut: Dâru'l-Fikr.

İbn Sa'd, (230/845). (1968). Tabakâtu'l-kübrâ. Beyrut: Dâru Sadr.

Kahveci, E. (2008). Strateji, stratejik yönetim ve stratejik yönetim modeli. Verimlilik Dergisi, 2008(4), 7-30.

Kapar, M. A. (1994). Ebu Leheb. Türkiye diyanet vakfi İslâm ansiklopedisi (ss. 178-179). İstanbul: TDV Yayınları.

Koçyiğit, T. (2015). Asabiyetten uhuvvete Medine'de Hz. Peygamber'in (s.a.v.) İslâm kardeşliğine dayalı bir toplum oluşturma stratejisi üzerine-. Dokuz Eylül Üniversitesi Illahiyat Fakültesi Dergisi, 1(41), 9-42.

Köksal, M. A. (1993). Dârülerkam. Türkiye diyanet vakfi İslâm ansiklopedisi ( 8, ss. 520-521). İstanbul: TDV Yayınlar1.

Kurt, E. (2000). Hz. Peygamber devrinde danışma meclisi (Şûrâ) (Yayımlanmamış Yüksek Lisans Tezi). Dokuz Eylül Üniversitesi, İzmir.

Kurt, E. (2012). Raşid halifeler dönemi yönetim anlayışına kaynaklık etmesi açısından cahiliye dönemi. EKEV Akademi Dergisi, 16(53), 295-306.

Kurt, E. (2020). Hz . Peygamber ( sav )' in kurduğu devlette millî irâde. Afyon Kocatepe Üniversitesi Sosyal Bilimler Dergisi, 22(November), 133-147.

Öz, Ş. (2018). Siyer soruları. İstanbul: Endülüs.

Özaktan, F. (2017). Kur'an'ın anlaşılmasında siyerin rolü, İstanbul: Marmara Akademi Yayınları.

Öztürk, L. (2001). İslâmiyet'in yayılmasında hicretin önemi:Habeşistan hicretleri örneği. Sakarya Üniversitesi İlahiyat Fakültesi Dergisi, (4), 7-24.

Savaş, R. (2017). Hz. Muhammed'in hayatında tek eşli olduğu dönemler. Siyer Arastırmaları Dergisi, (2), 11-25.

Şimşir, M. (2017). Hz. Peygamber'in İslâm tebliğine karşı şair ve siyasî liderlerin ilk tavırları ve şiir alanında yaşanan gelişmeler. Mütefekkir Aksaray Üniversitesi İslami İlimler Fakültesi Dergisi, 4(7), 41-61.

Söylemez, M. M. (2006). Müslümanlara uygulanan ilk ekonomik ve sosyal ambargo. M. M. Söylemez (Ed.), Örnek insan Hz. Muhammed. Çorum Çağrı Eğitim Vakfi.

Vâkıdî, (207/823). (1984). Kitabü'l-meğâzî I-III. (Marsden Jones, Ed.). Beyrut. 
Yılmaz, A. (2019). Mekkeli müşriklerin Hz. Muhammed'e karşı aşırı muhalefetlerinin öteki yüzü. Kilis 7 Aralık Üniversitesi İlahiyat Fakültesi Dergisi, 6(10), 59-89.

Yüksel, A. T. (1994). Yakındoğu'da ticaret merkezleri ve panayırlar. Selçuk Üniversitesi İlahiyat Fakültesi Dergisi, (5), 309-334.

\section{ETİK ve BİLIMSEL İLKELER SORUMLULUK BEYANI}

$\mathrm{Bu}$ çalışmanın tüm hazırlanma süreçlerinde etik kurallara ve bilimsel atıf gösterme ilkelerine riayet edildiğini yazar(lar) beyan eder. Aksi bir durumun tespiti halinde Afyon Kocatepe Üniversitesi Sosyal Bilimler Dergisi'nin hiçbir sorumluluğu olmayıp, tüm sorumluluk makale yazarlarına aittir. 